\title{
PENGARUH PENDEKATAN SAINTIFIK DAN PENDEKATAN CONTEXTUAL TEACHING AND LEARNING (CTL) TERHADAP PRESTASI BELAJAR SEJARAH SISWA DI SMA NEGERI 1 PEUKAN BARO KABUPATEN PIDIE
}

\author{
THE EFFECT OF SCIENCE AND CONTEXTUAL TEACHING AND LEARNING (CTL) \\ APPROACH TO STUDENT HISTORICAL ACHIEVEMENT ACHIEVEMENT IN SMA \\ NEGERI 1 PEUKAN BARO DISTRICT, PIDIE DISTRICT
}

\author{
Heri Fajri, ${ }^{1}$ Putri Raisa ${ }^{2}$ \\ ${ }^{1,2}$ Fakultas Keguruan dan Ilmu Pendidikan Universitas Jabal Ghafur \\ E-mail: herifajriunigha@gmail.com
}

Diterima: 15/03/2020;; Disetujui: 31/03/2020

\begin{abstract}
ABSTRAK
Penelitian ini bertujuan untuk mengetahui pengaruh pendekatan saintifik terhadap prestasi belajar sejarah dan untuk mengetahui terdapat pengaruh pendekatan Contextual Teaching and Learning (CTL) terdapat prestasi belajar sejarah. Penelitian ini menggunakan metode Kuantitatif dengan Pendekatan penelitian eksperimen. Populasi dalam penelitian ini berjumlah 205 siswa dari sembilan kelas. Sampel dalam penelitian ini adalah kelas X-1 sebagai kelas eksperimen dan X-4 sebagai kelas kontrol dengan jumlah 39 siswa. Teknik pengumpulan data dilakukan melalui pemberian tes sedangkan teknik pengolahan dan anilisis data diolah dengan menggunakan rumus uji t. Hasil penelitian menunjukkan bahwa hasil pengolahan data diperoleh nilai rata-rata untuk siswa kelas ekperimen $=76,3$ dan untuk siswa kelas kontrol di peroleh sebesar $=57,6$. Simpangan baku untuk kelas eksperimen $=32,797$ dan kelas kontrol $=23,63$ untuk hasil uji homogenitas $F_{\text {hitung }}=1,06$ dan $F_{\text {tabel }}$ $=2,92$ maka $F_{\text {hitung }} \leq \mathrm{F}_{\text {tabel }}$ sehingga dapat disimpulkan bahwa kedua kelas homongen. Untuk uji normalitas kelas ekperimen diperoleh hasil $X^{2}$ hitung $=-5,064$ dan $X_{\text {tabel }}^{2}=9,35$. Untuk uji normalitas kelas kontrol diperoleh hasil $X^{2}$ hitung $=-21,6239$ dan $X_{\text {tabel }}^{2}=9,35$. Oleh karena $X^{2}$ hitung $\leq X_{\text {tabel }}^{2}$ maka $\mathrm{H}_{\mathrm{o}}$ diterima dan dapat disimpulkan bahwa data dari kedua kelas mengikuti distribusi normal. Berdasarkan pengujian hipotesis dengan menggunakan uji t diperoleh nilai $t_{\text {hitung }}=5,16$ dengan signifikan $t_{\text {tabel }}=1,68$ maka hipotesisnya adalah terima $\mathrm{H}_{\mathrm{a}}$ dan tolak $\mathrm{H}_{\mathrm{o}}$.
\end{abstract}

Kata Kunci: Pendekatan Saintifik, Pendekatan CTL, Prestasi Belajar 


\begin{abstract}
This study aims to determine the effect of the scientific approach to historical learning achievement and to find out effect of the Contextual Teaching and Learning (CTL) approach there is historical learning achievement. This study uses a quantitative method with an experimental research approach. The population in study amounted to 205 students from nine classes. Using sample in class X-1 as an experimental class and X-4 as a control class with a total of 39 students. Data collection techniques were carried out through test administration while data processing and analysis techniques were processed using the t test formula. The results showed that the results of data processing obtained an average value for experimental class students $=76.3$ and for the control class students obtained $=57.6$. The standard deviation for the experimental class $=32.797$ and the control class $=23.63$ for the homogeneity test results Fcount $=1.06$ and Ftable $=2.92$ then Fcount $\leq$ Ftable so that it can be concluded that the two classes are homongent. To test the normality of the experimental class the results obtained X2 count $=-5.064$ and X2 table $=9.35$. For the normality test of the control class the results obtained $X 2$ count $=-21.6239$ and $X 2$ table $=9.35$. Because X2 arithmetic $\leq X 2$ table then Ho is accepted and it can be concluded that data from both classes follows the normal distribution. Based on testing the hypothesis using the $t$ test, the value of tcount $=5.16$ with a significant ttable $=1.68$ is obtained, the hypothesis is accepted Ha and reject Ho.
\end{abstract}

Keywords: the scientific approach, Contextual Teaching and Learning (CTL), learning achievement

\title{
PENDAHULUAN
}

Pendidikan merupakan penentu untuk memajukan kecerdasan suatu bangsa. Seperti yang tercantum dalam Undang Undang Dasar 1945 bahwa salah satu tujuan negara Indonesia yaitu mencerdaskan kehidupan bangsa dengan majunya suatu pendidikan maka pendidikan yang ada di Indonesia akan bermutu. Menurut Undang-Undang No. 20 tahun 2003 tentang sistem pendidikan nasional disebutkan bahwa pendidikan adalah usaha sadar dan terencana untuk mewujudkan suasana belajar dan proses pembelajaran agar siswa aktif mengembangkan potensi dirinya untuk memiliki kekuatan spiritual keagaman, pengendalian diri, kepribadian, akhlak mulia, serta keterampilan yang diperlukan dirinya, masyarakat, bangsa dan negara.
Pendidikan adalah suatu proses pembentukan dalam diri kita yaitu dalam pertumbuhan rohani dan jasmani, sehat otaknya dan baik budi pekertinya, sehingga dapat mencapai cita-cita yang diinginkan dan tercapai bahagia lahir dan batinnya. Secara sadar maupun tidak sadar pendidikan sudah menjadi bagian dari dalam hidup kita dan tidak dapat kita hindari takdirnya, serta pendidikan merupakan suatu peristiwa yang kompleks, yaitu peristiwa terjadinya serangkaian komunikasi antara manusia dengan lingkungannya, sehingga manusia tumbuh dan berkembang sebagai pribadi yang utuh. Peningkatan kualitas pendidikan dapat dilihat dari beberapa faktor yang menunjang. Salah satu tolak ukur 
Jurnal Geuthèë: Penelitian Multidisiplin Vol. 03, No. 01, (Maret, 2020), pp. 400-416.
Pengaruh Pendekatan Saintifik Dan Pendekatan Contextual Teaching And Learning (CTL) Terhadap Prestasi Belajar Sejarah Siswa Di Sma Negeri 1 Peukan Baro Kabupaten Pidie Heri Fajri, Putri Raisa peningkatan kualitas pendidikan yaitu adalah pemebelajaran. Menurut Yusufhadi (2004: 545), pembelajaran adalah suatu usaha yang disengaja, bertujuan, dan terkendali agar orang lain belajar atau terjadi perubahan yang relatif menetap pada diri orang lain.

Usaha tersebut dapat dilakukan oleh seseorang atau sekelompok orang yang memiliki kemampuan dan kompetensi dalam merancang dan atau mengembangkan sumber belajar yang diperlukan, dapat pula dikatakan bahwa pembelajaran adalah usaha yang dilakukan oleh pendidik atau orang dewasa lainnya untuk mencapai hasil belajar yang maksimal.

Jika seorang individu menginginkan perubahan dalam dirinya maka orang tersebut harus berusaha, dan aktivitas berusaha inilah yang dimaksud dengan belajar. Belajar adalah suatu proses untuk mengubah peformansi yang tidak terbatas pada keterampilan, tetapi juga meliputi fungsi-fungsi, seperti skill, persepsi, emosi, proses berpikir, sehingga dapat menghasilkan perbaikan perfomansi. Tentu saja bagi seorang siswa belajar sangatlah penting untuk merubah kehidupannya. Oleh karena itu perlu adanya tugas dan peran dari seorang guru untuk mencapai keberhasilan dalam belajar, agar meningkatkan hasil belajar dari siswa. Bagi seorang guru menggunakan pendekatan pendekatan atau pembelajaran yang tepat adalah cara yang efisien untuk memberikan pelajaran terhadap siswanya. Tujuan utama pembelajaran ilmu pengetahuan sosial ialah untuk mengembangkan potensi siswa agar peka terhadap masalah sosial yang terjadi di masyarakat, memiliki sikap mental positif terhadap perbaikan segala ketimpangan yang terjadi, dan terampil mengatasi setiap masalah yang terjadi sehari-hari baik yang menimpa diriya sendiri maupun yang menimpa masyarakat. Tujuan tersebut dapat dicapai manakala mata pelajaran IPS terpadu dapat diorganisasikan secara baik oleh guru. Sistem pembelajaran yang ada sekarang ini yaitu masih terpusat pada guru yang memberikan materi hanya dengan satu arah atau teacher centered, karena guru masih menggunakan teacher centered dan siswa tidak diberi kesempatan untuk mengembangkan pengetahuannya tentang materi yang diberikan sehingga yang diterima siswa hanyalah penonjolan tingkat hafalan dari sekian macam materi yang berikan, tetapi belum diikuti oleh pengertian dan pemahaman yang mendalam yang bisa digunakan dalam kehidupan sehari-harinya, dan kurang aktifnya siswa dalam proses pembelajaran sehingga menyebabkan hasil belajar siswa masih ada yang belum tuntas.

Berdasarkan hasil observasi awal di SMA Negeri 1 Peukan Baro masih banyak hasil belajarnya yang belum tuntas. Siswa dengan nilai yang masih berada di bawah. Setelah melakukan survei dan melihat keadaan di SMA Negeri 1 Peukan Baro dapat terlihat bahwa nilai dari hasil belajar yang didapat siswa masih rendah. 
Dikarenakan proses pembelajaran masih menggunakan teacher centered, serta ke aktifan siswa dalam pembelajaran masih kurang. Selain itu peran guru lebih terlihat dominan pada saat melakukan pembelajaran dibandingkan dengan siswanya. Pemahaman yang di dapat siswa hanya sebatas apa yang diberikan oleh dari gurunya saja. Sehingga siswa tidak bisa mengembangkan materi yang diberikan tersebut dan siswa hanya mengikuti permintaan guru sehingga menyebabkan siswanya kurang kreatif dalam pembelajaran. Dan hal tersebut dapat mempengaruhi hasil belajar siswa. Banyak pendekatan pembelajaran yang dapat dilakukan guru agar dapat meningkatkan hasil belajar siswa seperti pendekatan pembelajaran kooperatif dan lain sebagainya, tidak semua pendekatan memiliki makna yang dapat diambil dari suatu pembelajaran tersebut dan masih belum banyak diimplementasikan di sekolah sekolah. Maka dari itu pada penelitian ini digunakan pendekatan pembelajaran Contextual Teaching and Learning, karena pendekatan tersebut dapat dikatakan cocok dan memiliki keunggulan.

Pendekatan pembelajaran Contextual Teaching and Learning (CTL) adalah konsep belajar yang membantu guru mengaitkan antara materi yang diajarkannya dengan situasi dunia nyata siswa dan mendorong antara pengetahuan yang dimilikinya dengan penerapannya dalam kehidupan mereka sebagai anggota keluarga dan masyarakat. Dengan menghubungkan materi materi yang ada yang dikaitkan dengan kehidupan sehari-harinya maka siswa dapat memiliki pengetahuan yang fleksibel dalam kehidupannya.

Berdasarkan uraian di atas, maka peneliti mengadakan penelitian berjudul Pengaruh Pendekatan Saintifik dan Pendekatan Contextual Teaching and Learning (CTL) Terhadap Prestasi Siswa di SMA Negeri 1 Peukan Baro Kabupaten Pidie.

\section{Pendekatan Saintifik}

Pendekatan saintifik adalah suatu proses pembelajaran yang dirancang supaya peserta didik secara aktif mengkonstruk konsep, hukum, atau prinsip melalui kegiatan mengamati, merumuskan masalah, mengajukan/merumuskan hipotesis, mengumpulkan data dengan berbagai teknik, menganalisis data, menarik kesimpulan, dan mengkomunikasikan (Hosnan, 2014 :34).

Pendekatan saintifik dimaksukan untuk memberikan pemahaman kepada peserta didik dalam mengenal, memahami berbagai materi menggunakan pendekatan ilmiah. Penerapan pendekatan saintifik dalam pembelajaran melibatkan keterampilan proses seperti mengamati, mengklasifikasi, mengukur, meramalkan, menjelaskan, dan menyimpulkan. Pendekatan saintifik memiliki karakteristik berpusat pada peserta didik, melibatkan keterampilan proses sains dalam mengkonstruk konsep; hukum; atau prinsip, melibatkan proses kognitif yang potensial merangsang 
Jurnal Geuthèë: Penelitian Multidisiplin Vol. 03, No. 01, (Maret, 2020), pp. 400-416.
Pengaruh Pendekatan Saintifik Dan Pendekatan Contextual Teaching And Learning (CTL) Terhadap Prestasi Belajar Sejarah Siswa Di Sma Negeri 1 Peukan Baro Kabupaten Pidie Heri Fajri, Putri Raisa perkembangan intelek (keterampilan berpikir), serta dapat mengembangkan karakter peserta didik. Pendekatan saintifik adalah konsep dasar yang mewadahi, menginspirasi, menguatkan, dan melatari pemikiran tentang bagaimana metode pembelajaran diterapkan berdasarkan teori tertentu (Kosasih, 2000:70).

Daryanto (2014:51) mengungkapkan bahwa pembelajaran dengan pendekatan saintifik adalah proses pembelajaran yang dirancang sedemikian rupa agar peserta didik secara aktif mengkonstruksi konsep, hukum atau prinsip melalui tahapantahapan mengamati, merumuskan masalah, mengajukan atau merumuskan hipotesis, mengumpulkan data dengan berbagai teknik, menganalisis data, menarik kesimpulan dan mengkomunikasikan konsep, hukum atau prinsip yang ditemukan.

Berdasarkan uraian yang telah dijelaskan, maka pendekatan saintifik yang dimaksud dalam penelitian ini adalah sesuatu yang digunakan dalam proses pembelajaran yang dirancang supaya peserta didik secara aktif mengkonstruk konsep, hukum, atau prinsip melalui pendekatan ilmiah. Pendapat para ahli di atas dapat disimpulkan bahwa pendekatan saintifik merupakan pendekatan yang berpusat kepada siswa agar siswa secara aktif mengkonstruksi konsep, hukum atau prinsip melalui tahapantahapan mengamati, merumuskan masalah, mengajukan atau merumuskan hipotesis, mengumpulkan data dengan berbagai teknik, menganalisis data, menarik kesimpulan dan mengkomunikasikan konsep, hukum atau prinsip yang ditemukan.

\section{Pendekatan Contextual Teaching and Learning (CTL)}

\section{Contextual Teaching and Learning}

(CTL) adalah sebuah proses pendidikan yang bertujuan menolong para siswa melihat makna di dalam materi akademik yang mereka pelajari dengan cara menghubungkan subyek-subyek akademik yang mereka pelajari dengan konteks dalam kehidupan keseharian mereka, yaitu dengan konteks keadaan pribadi, sosial dan budaya mereka. Untuk mencapai tujuan ini, sistem tersebut meliputi delapan komponen berikut: membuat keterkaitan-keterkaitan yang bermakna, melakukan pekerjaan yang berarti, melakukan pembelajaran yang diatur sendiri, melakukan kerjasama, berpikir kritis dan kreatif, membantu individu untuk tumbuh dan berkembang, mencapai standar yang tinggi, dan menggunakan penilaian autentik (Setiawan, 2007:67).

\section{Contextual Teaching and learning} adalah sebuah proses pendidikan yang bertujuan menolong para siswa melihat makna di dalam materi akademik yang mereka pelajari dengan cara menghubungkan subyek-subyek akademik dengan konteks dalam kehidupan keseharian mereka, yaitu dengan konteks keadaan pribadi, sosial, dan budaya mereka (Alwasilah, 2008: 67). 
Pengaruh Pendekatan Saintifik Dan Pendekatan Contextual Teaching And Learning (CTL) Terhadap Prestasi Belajar Sejarah Siswa Di Sma Negeri 1 Peukan Baro Kabupaten Pidie Heri Fajri, Putri Raisa

Depdiknas (2007:18) mendefinisikan Contextual Teaching and Learning (CTL) sebagai berikut: Suatu proses pendidikan yang holistik dan bertujuan membantu siswa untuk memahami makna materi pelajaran yang dipelajarinya dengan mengaitkan materi tersebut dengan konteks kehidupan mereka sehari-hari (konteks pribadi, sosial dan kultural), sehingga siswa memiliki pengetahuan/keterampilan yang secara fleksibel dapat diterapkan (ditransfer) dari satu permasalahan/konteks ke permasalahan/konteks lainnya. Beberapa komponen utama dalam pembelajaran Kontekstual:

a. Melakukan hubungan yang bermakna (Making Meaningful Connections). Keterkaitan yang mengarah pada makna adalah jantung dari pembelajaran dan pengajaran kontekstual. Ketika siswa dapat mengkaitkan isi dari mata pelajaran akademik, ilmu pengetahuan alam. Atau sejarah dengan pengalamannya mereka sendiri, mereka menemukan makna, dan makna memberi mereka alasan untuk belajar. Mengkaitkan pembelajaran dengan kehidupan seseorang membuat proses belajar menjadi hidup dan keterkaitan inilah inti dari CTL.

b. Melakukan kegiatan-kegiatan yang berarti (Doing Significant Works) Model pembelajaran ini menekankan bahwa semua proses pembelajaran yang
Jurnal Geuthèë: Penelitian Multidisiplin Vol. 03, No. 01, (Maret, 2029), pp. 400-416

dilakukan di dalam kelas harus punya arti bagi siswa sehingga mereka dapat mengkaitkan materi pelajaran dengan kehidupan siswa.

c. Belajar yang diatur sendiri (SelfRegulated Learning) Pembelajaran yang diatur sendiri, merupakan pembelajaran yang aktif, mandiri, melibatkan kegiatan menghubungkan masalah ilmu dengan kehidupan sehari-hari dengan cara-cara yang berarti bagi siswa. Pembelajaran yang diatur siswa sendiri, memberi kebebasan kepada siswa menggunakan gaya belajarnya sendiri.

d. Bekerjasama (collaborating) Siswa dapat bekerja sama. Guru membantu siswa bekerja secara efektif dalam kelompok, membantu siswa bekerja secara efektif dalam kelompok, membantu mereka memahami bagaimana mereka saling mempengaruhi dan saling berkomunikasi.

e. Berpikir kritis dan kreatif (Critical dan Creative Thinking)

Pembelajaran kontekstual membantu siswa mengembangkan kemampuan berpikir tahap tinggi, nerpikir kritis dan berpikir kreatif. Berpikir kritis adalah suatu kecakapan nalar secara teratur, kecakapan sistematis dalam menilai, memecahkan masalah menarik keputusan, memberi keyakinan, 
Pengaruh Pendekatan Saintifik Dan Pendekatan Contextual Teaching And Learning (CTL) Terhadap Prestasi Belajar Sejarah Siswa Di Sma Negeri 1 Peukan Baro Kabupaten Pidie Heri Fajri, Putri Raisa menganalisis asumsi dan pencarian ilmiah. Berpikir kreatif adalah suatu kegiatan mental untuk meningkatkan kemurnian, ketajaman pemahaman dalam mengembangkan sesuatu.

f. Mengasuh atau memelihara pribadi siswa (Nuturing The Individual)

Dalam pembelajaran kontekstual siswa bukan hanya mengembangkan kemampuan-kemampuan intelektual dan keterampilan, tetapi juga aspek-aspek kepribadian: integritas pribadi, sikap, minat, tanggung jawab, disiplin, motif berprestasi, dsb. Guru dalam pembelajaran kontekstual juga berperan sebagai konselor, dan mentor. Tugas dan kegiatan yang akan dilakukan siswa harus sesuai dengan minat, kebutuhan dan kemampuannya.

g. Mencapai standar yang tinggi (Reaching High Standards)

Pembelajaran kontekstual diarahkan agar siswa berkembang secara optimal, mencapai keunggulan (excellent). Tiap siswa bisa mencapai keunggulan, asalkan sia dibantu oleh gurunya dalam menemukan potensi dan kekuatannya.

h. Menggunakan Penilaian yang otentik (Using Authentic Assessment)

Penilaian autentik menantang para siswa untuk menerapkan informasi dan keterampilan akademik baru dalam situasi nyata untuk tujuan tertentu. Penilaian autentik merupakan antitesis dari ujian stanar, penilaian autentik memberi kesempatan kepada siswa untuk menunjukkan kemampuan terbaik mereka sambil mempertunjukkan apa yang sudah mereka pelajari.

Pembelajaran kontekstual yang dimaksud adalah suatu bentuk pembelajaran yang menekankan kepada proses keterlibatan peserta didik secara utuh agar dapat menemukan materi yang dipelajari serta menghubungkannya dengan situasi kehidupan nyata untuk diterapkan dalam kehidupan mereka, baik dalam lingkungan keluarga maupun lingkungan masyarakat, dengan tujuan untuk menemukan makna materi tersebut bagi kehidupannya.

\section{Prestasi Belajar}

Menurut Sumadi Suryabrata (2006: 297), prestasi dapat pula didefinisikan sebagai berikut: "nilai merupakan perumusan terakhir yang dapat diberikan oleh guru mengenai kemajuan/prestasi belajar siswa selama masa tertentu". Jadi, prestasi adalah hasil usaha siswa selama masa tertentu melakukan kegiatan.

Menurut pendapat Hutabarat (2005: 1112), hasil belajar dibagi menjadi empat golongan yaitu :

a. Pengetahuan, yaitu dalam bentuk bahan informasi, fakta, gagasan, keyakinan, prosedur, hukum, kaidah, standar, dan konsep lainya. 
b. Kemampuan, yaitu dalam bentuk kemampuan untuk menganalisis, mereproduksi, mencipta, mengatur, merangkum, membuat generalisasi, berfikir rasional dan menyesuaikan.

c. Kebiasaaan dan keterampilan, yaitu dalam bentuk kebiasaan perilaku dan keterampilan dalam menggunakan semua kemampuan.

d. Sikap, yaitu dalam bentuk apresiasi, minat, pertimbangan dan selera.

Dari pendapat di atas dapat disimpulkan bahwa prestasi belajar adalah hasil usaha siswa yang dapat dicapai berupa penguasan pengetahuan, kemampuan kebiasaan dan keterampilan serta sikap setelah mengikuti proses pembelajaran yang dapat dibuktikan dengan hasil tes. Prestasi belajar merupakan suatu hal yang dibutuhkan siswa untuk mengetahui kemampuan yang diperolehnya dari suatu kegiatan yang disebut belajar.

\section{METODE PENELITIAN}

\section{Pendekatan dan Jenis Penelitian}

Jenis penelitian ini adalah penelitian eksperimen semu (quasi experiment) dengan metode kuantitatif. Tujuan metode kuantitatif menurut Sugiyono (2013: 14) adalah menunjukan hubungan antar variabel, menguji teori, serta mencari generalisasi yang mempunyai nilai prediktif. Sedangkan tujuan penelitian kuasi eksperimen adalah memperoleh informasi yang merupakan perkiraan dari informasi yang dapat diperoleh dari eksperimen yang sesungguhnya dengan keadaan yang tidak memungkinkan untuk mengontrol atau memanipulasi semua variabel yang relevan (Suryabrata, 2013: 58).

Penelitian ini melibatkan dua kelompok, yaitu kelompok kontrol dan kelompok eksperimen. Kelompok kontrol merupakan kelompok yang mengikuti pembelajaran menggunakan pendekatan saintifik. Kelompok eksperimen yaitu kelompok yang mengikuti pembelajaran dengan pendekatan saintifik dengan pendekatan CTL (Contextual Teaching and Learning).

\section{Populasi dan Sampel}

Populasi target pada penelitian ini adalah seluruh siswa SMA Negeri 1 Peukan Baro Kabupaten Pidie. Populasi terjangkau pada penelitian ini adalah seluruh siswa SMA Negeri 1 Peukan Baro Kabupaten Pidie kelas X pada semester Ganjil tahun 2018/2019 yang terbagi dalam 8 kelas. Jumlah siswa kelas X SMA Negeri 1 Peukan Baro Kabupaten Pidie sekitar 160 siswa.

Adapun teknik pengambilan sampel dari populasi dilakukan dengan teknik simple random sampling (pengambilan sampel secara acak sederhana). Dikatakan sederhana karena tidak memerlukan perhatian pada kerumitan dengan adanya keberagaman ciri dan atau kondisi, dan caranya (teknisnya) pun amat sangat sederhana. Untuk itu, penempatan Kelas X SMA Negeri 1 Peukan Baro Kabupaten Pidie dilakukan secara acak oleh pihak sekolah tanpa didasarkan atas peringkat dan nilai. Dengan 
Pengaruh Pendekatan Saintifik Dan Pendekatan Contextual Teaching And Learning (CTL) Terhadap Prestasi Belajar Sejarah Siswa Di Sma Negeri 1 Peukan Baro Kabupaten Pidie Heri Fajri, Putri Raisa demikian, diasumsikan bahwa setiap kelas pada kelas Kelas X SMA Negeri 1 Peukan Baro Kabupaten Pidie ini merupakan Kelas yang relatif homogen.

Sedangkan sampel dari penelitian ini adalah 2 kelas, sampel penelitian adalah Kelas X A menggunakan pendekatan saintifik Kelas XB. Satu Kelas dijadikan kelas kontrol yaitu Kelas XA dan satu kelas dijadikan kelas eksperimen yaitu Kelas X B sebagai Kontrol menggunakan Contextual Teaching and Learning (CTL) dengan jumlah siswa masing-masing sebanyak 26 siswa.

\section{Teknik Pengumpulan Data}

Data kuantitatif diperoleh dari prestasi belajar siswa kelas X IPS (1) dan kelas X IPS (2) dan dari pelaksanaan. Data tersebut diperoleh dengan cara tes. Tes adalah suatu proses memperoleh, mengevaluasi, dan memberi skor terhadap suatu aspek perilaku individu dengan menggunakan prosedur terstandar (Reynolds, 2010:23). Pada penelitian ini, tes digunakan untuk mengukur prestasi belajar siswa kelas eksperimen dan kelas kontrol.

Metode tes yang digunakan adalah pretest dan post-test. Sedangkan, data kualitatif diperoleh melalui lembar observasi keterlaksanaan pembelajaran di kedua kelas.

\section{Instrumen Penelitian}

Instrumen yang digunakan dalam penelitian ini adalah instrumen pembelajaran, yakni RPP dan LKS (lembar kegiatan siswa), instrumen pengambilan data berupa instrumen tes, yaitu soal pre-test dan post-test, serta instrumen non-tes berupa lembar observasi keterlaksanaan pembelajaran. Ketiga instrumen ini disusun berdasarkan Kompetensi Inti dan Kompetensi Dasar Kurikulum 2013 mata pelajaran matematika SMA kelas $\mathrm{X}$ untuk kelompok wajib pada materi yang berkaitan.

\section{Teknik Analisis Data}

Setelah data terkumpul, tahap selanjutnya adalah penganalisis data. Pengolahan data dilakukan dalam suatu penelitian agar peneliti dapat merumuskan hasil penelitiannya. Data yang terkumpul adalah jawaban siswa terhadap soal yang diberikan. Rata-rata (X) dapat dihitung dengan menggunakan rumus Sudjana (2005:70) yaitu :

$$
\bar{X}=\frac{\sum f i x i}{\sum f i}
$$

Sedangkan simpangan baku (s) dapat dihitung dengan menggunakan rumus Sudjana (2005:95) yaitu :

$$
S^{2}=\frac{\left\lfloor\left(n \sum f_{i} x_{i}^{2}\right)-\left(f_{i} x_{i}\right)^{2}\right\rfloor}{n(n-1)}
$$

Dimana $:(X)=$ Rata-rata

$f i \quad=$ Banyak murid dalam interval tertentu (frekwensi)

$$
\begin{array}{ll}
\mathrm{n} & =\text { Banyak data siswa } \\
\mathrm{S} & =\text { standar deviasi }
\end{array}
$$

Untuk mencari varian gabingan menurut Sudjana (2005:239) dapat digunakan dengan rumus: 


$$
S^{2}=\frac{\left(n_{1}-1\right) S_{1}^{2}+\left(n_{2}-1\right) S_{2}^{2}}{n_{1}+n_{2}-2}
$$

Tabel distribusi frekwensi dengan panjang kelas yang sama menurut Sudjana (2005:47) dapat dibuat dengan mengikuti langkah-langkah sebagai berikut:

a. Rentang yaitu data terbesar dikurangi data terkecil

b. Banyak kelas interval yang diperlukan, untuk ini menggunakan aturan Sturges yaitu banyak kelas $=1 .+3,3 \log n$

c. Panjang kelas interval (p)

$$
F=\frac{\text { Varians } T \text { Terbesar }}{\text { Varians Terkecil }}
$$

d. Ujung bawah kelas interval pertama, untuk ini biasa dipilih sama dengan data terkecil atau nilai data yang lebih kecil data terkecil tetapi selisihnya harus kurang dari panjang kelas yang sudah ditentukan. Selanjutnya untuk menguji normalitas data digunakan Stantistik Chi Kuadrat seperti yang dikemukakan Sudjana (2005:273) sebagai berikut

$$
X^{2}=\sum_{i=1}^{k} \frac{\left(O_{i}-E_{i}\right)^{2}}{E_{i}}
$$

$\begin{array}{llll}\text { Dengan: } & \mathrm{X}^{2} & = & \text { Chi Kuadrat } \\ & \mathrm{O}_{\mathrm{i}} & = & \text { Frekuensi } \\ \text { Pengamatan } & \mathrm{E}_{\mathrm{i}} & = & \text { Frekuensi yang } \\ \text { diharapkan } & \end{array}$ distribusi Chi-kuadrat dengan $\mathrm{dk}=\mathrm{k}-1$, dan taraf signifikan $\alpha=0,05$ untuk keperluan mencari nilai
$\mathrm{E}_{\mathrm{i}}$, dibuat tabel frekuensi yang diharapkan dan frekuensi hasil pengamatan.

Adapun statistik lain yang diperlukan sehubungan dengan penggunaan uji $-\mathrm{t}$ adalah :

$$
t=\frac{\overline{X-\mu_{O}}}{\frac{S}{\sqrt{n}}}
$$

Karena uji yang dilakukan adalah uji pihak kanan, maka menurut Sudjana (2005:243) "Kriteria pengujian yang berlaku ialah: terima Ho jika $t_{\text {hitung }}<t_{\text {tabel }}$ dan tolak Ho jika $t$ mempunyai harga-harga lain. Derajat kebebasan untuk daftar distribusi t ialah (n-2) dan peluang (1- $\alpha)$ ". Dengan taraf nyata $\alpha=0,05$ Pengujian hipotesis dilakukan dengan uji t, dengan kriteria sebagai berikut :

Dan kriteria pengujian sebagai berikut :

- Tolak Ho jika $t_{\text {hitung }} \geq t_{\text {tabel }}$

- Terima Ho jika $t_{\text {hitung }}<t_{\text {tabel }}$

Ketentuan hipotesis dalam penelitian ini adalah :

Ho = Pendekatan Pembelajaran Saintifik berpengaruh terhadap prestasi belajar siswa SMA Negeri 1 Peukan Baro Kabupaten Pidie. $\mathrm{Ha}=$ Pendekatan Pembelajaran CTL (Contextual Teaching and Learning) berpengaruh terhadap prestasi belajar siswa SMA Negeri 1 Peukan Baro Kabupaten Pidie.

\section{HASIL PENELITIAN DAN PEMBAHASAN}

Pengumpulan data dilaksaanakan dengan mengadakan tes akhir pada masing-masing kelas 
Pengaruh Pendekatan Saintifik Dan Pendekatan Contextual Teaching And Learning (CTL) Terhadap Prestasi Belajar Sejarah Siswa Di Sma Negeri 1 Peukan Baro Kabupaten Pidie Heri Fajri, Putri Raisa eksperimen dan kelas kontrol. Berikut rincian nilainya yaitu sebagai berikut:

\section{Nilai Pengolahan Data Kelas Eksperimen}

Nilai pengolahan data kelas eksperimen adalah nilai yang diperoleh dari kelas penerapan Contextual Teaching and Learning (CTL), nilainilai tersebut diurutkan dari yang terkecil sampai yang terbesar seperti yang terdapat dalam tabel diatas agar lebih mudah untuk mengolah data, diantaranya:

\section{a. Menentukan Rentang}

Rentang (R) adalah Nilai tertinggi - Nilai terendah

$$
\begin{aligned}
& =90-60 \\
& =30
\end{aligned}
$$

b. Menentukan banyak kelas interval

Interval Kelas (K) adalah 1+ 3,3 $\log n$

$$
\begin{aligned}
& =1+3,3 \log 20 \\
& =1+3,3(1,301) \\
& =1+4,29 \\
& =5,29(\mathrm{~K}=6)
\end{aligned}
$$

c. Menentukan panjang kelas (P)

$$
\begin{aligned}
& \mathrm{P}=\frac{\text { rentang }}{\text { banyak kelas }} \\
& \mathrm{P}=\frac{30}{6} \\
& \mathrm{P}=5
\end{aligned}
$$

\begin{tabular}{|c|c|c|c|c|c|c|}
\hline $\mathrm{N}$ & $\begin{array}{l}\text { Inter } \\
\text { val } \\
\text { kelas }\end{array}$ & $\begin{array}{l}F \\
i\end{array}$ & $X i$ & $X i^{2}$ & $F i X i$ & $F i X i^{2}$ \\
\hline 1 & $\begin{array}{l}60- \\
64\end{array}$ & 1 & 62 & 3844 & 62 & 3844 \\
\hline 2 & $\begin{array}{l}65- \\
69\end{array}$ & 2 & 67 & 4489 & $\begin{array}{c}13 \\
4\end{array}$ & 17956 \\
\hline 3 & $\begin{array}{l}70- \\
74\end{array}$ & 5 & 72 & 5184 & $\begin{array}{c}36 \\
0\end{array}$ & 129600 \\
\hline 4 & $\begin{array}{l}75- \\
79\end{array}$ & 5 & 77 & 5929 & $\begin{array}{c}38 \\
5\end{array}$ & 148225 \\
\hline 5 & $\begin{array}{l}80- \\
84\end{array}$ & 5 & 82 & 6724 & $\begin{array}{c}41 \\
0\end{array}$ & 168100 \\
\hline 6 & $\begin{array}{l}85- \\
90\end{array}$ & 2 & $\begin{array}{c}87, \\
5\end{array}$ & $\begin{array}{c}7656 \\
56\end{array}$ & $\begin{array}{c}17 \\
5\end{array}$ & 30625 \\
\hline & $\begin{array}{c}\text { Juml } \\
\text { ah }\end{array}$ & 2 & $\begin{array}{r}447 \\
, 5\end{array}$ & $\begin{array}{c}33826 \\
, 26\end{array}$ & $\begin{array}{l}15 \\
26\end{array}$ & 498350 \\
\hline
\end{tabular}

Setelah menentukan rentang, banyaknya kelas dan panjang kelas tahap selanjutnya adalah menentukan distribusi frekuensi dari nilai eksperimen. Untuk lebih jelas dapatdilihat pada tabel dibawah ini :

Nilai kelas eksperimen

Nilai rata-rata tes akhir siswa kelas eksperimen sebagai berikut:

$$
\begin{aligned}
\bar{x}_{1} & =\frac{\sum f_{i} x_{i}}{\sum f_{i}} \\
& =\frac{1526}{20} \\
& =76,3
\end{aligned}
$$

Selanjutnya Varians dan simpangan baku dapat diperoleh: 


$$
\begin{aligned}
\mathrm{s}_{1}^{2} & =\frac{n \sum_{\mathrm{i}=1}^{\mathrm{n}} \mathrm{X}_{1}^{2}-\left(\sum_{\mathrm{i}=0}^{\mathrm{n}} \mathrm{X}_{1}\right)^{2}}{n(n-1)} \\
s_{1}^{2} & =\frac{20(33826,26)-(447,5)^{2}}{20(20-1)} \\
& =\frac{20(676525,2)-200256,25}{20(19)} \\
s_{1}^{2} & =\frac{476268}{380} \\
s_{1}^{2} & =1253,336 \\
\mathrm{~s}_{1} & =\sqrt{1253,336} \\
s_{1} & =35,40
\end{aligned}
$$

\section{Nilai pegolahan data kelas kontrol}

Nilai pengolahan data kelas kontrol adalah nilai yang diperoleh dari kelas dengan penerapan model pembelajaran saintifik. Tahap pertama dalam pengolahan data adalah:

\section{a. Menentukan Rentang}

Rentang (R) adalah Nilai tertinggi -

Nilai terendah

$$
\begin{aligned}
& =80-20 \\
& =60
\end{aligned}
$$

b. Menentukan banyak kelas interval Interval Kelas $(\mathrm{K})$ adalah $1+3,3 \log \mathrm{n}$

$$
\begin{aligned}
& =1+3,3 \log 19 \\
& =1+3,3(1,27) \\
& =1+4,19 \\
& =5,19(\mathrm{~K}=6)
\end{aligned}
$$

c. Menentukan panjang kelas (P)

$$
\begin{aligned}
& \mathrm{P}=\frac{\text { rentang }}{\text { banyak kelas }} \\
& \mathrm{P}=\frac{60}{6} \\
& \mathrm{P}=10
\end{aligned}
$$

Setelah menentukan rentang, banyaknya kelas dan panjang kelas tahap selanjutnya adalah menentukan distribusi frekuensi dari nilai kelas kontrol. Untuk lebih jelas dapatdilihat pada tabel dibawah ini:

Daftar Distribusi Frekuensi Nilai kontrol

\begin{tabular}{|c|c|c|c|c|c|r|}
\hline No & $\begin{array}{c}\text { Interval } \\
\text { kelas }\end{array}$ & $F i$ & $X i$ & $x i^{2}$ & fixi & fixi \\
\hline 1 & $20-29$ & 2 & 24,5 & 600,25 & 49 & 2401 \\
\hline 2 & $30-39$ & 2 & 34,5 & 1190,25 & 69 & 4761 \\
\hline 3 & $40-49$ & 3 & 54,5 & 1980,25 & 163,5 & 26732,2 \\
\hline 4 & $50-59$ & 3 & 60.5 & 2970,25 & 181,5 & 14641 \\
\hline 5 & $60-69$ & 4 & 64,5 & 4160,25 & 258 & 66564 \\
\hline 6 & $70-80$ & 5 & 75 & 5625 & 375 & 140625 \\
\hline & Jumlah & 19 & 297,5 & 16526,25 & 1096 & 255724,2 \\
\hline
\end{tabular}

Nilai rata-rata tes akhir siswa kelas kontrol sebagai berikut:

$$
\begin{gathered}
\bar{x}_{2}=\frac{\sum f_{i} x_{i}}{\sum f_{i}} \\
=\frac{1096}{19} \\
=57,6
\end{gathered}
$$

Selanjutnya Varians dan simpangan baku dapat diperoleh:

$$
\begin{aligned}
s_{2}^{2} & =\frac{n \sum_{\mathrm{i}=1}^{\mathrm{n}} \mathrm{X}_{2}^{2}-\left(\sum_{\mathrm{i}=0}^{\mathrm{n}} \mathrm{X}_{2}\right)^{2}}{n(n-1)} \\
& =\frac{19(16526,25)-(297,5)^{2}}{19(19-1)} \\
s_{2}^{2} & =\frac{(313998,75)-88506,25}{19(18)}
\end{aligned}
$$




$$
\begin{aligned}
s_{2}^{2} & =\frac{402505}{342} \\
s_{2}^{2} & =1176,9152 \\
& =\sqrt{1176,9152} \\
s_{2} & =34,30
\end{aligned}
$$

\section{Uji Homogenitas}

Uji homogenitas digunakan untuk mengetahui sampel penelitian ini berasal dari populasi yang sama, sehingga hasil penelitian dapat berlaku bagi populasi. Untuk menguji homogenitas digunakan rumus:

$$
F=\frac{s_{1}^{2}}{s_{2}^{2}}
$$

Hipotesis yang akan diuji pada taraf signifikan $\alpha=0,05$. Untuk pengujian homogenitas dua sampel dapat ditulis:

$$
H_{o}:{\sigma_{1}}^{2}=\sigma_{2}{ }^{2} \text { (varians data }
$$

homogen)

Dengan kriteria pengujiannya adalah jika Fhitung $\leq \mathrm{f}_{\alpha}\left(\mathrm{n}_{1}-1, \mathrm{n}_{2}-1\right)$, dalam hal lain $\mathrm{H}_{\mathrm{o}}$ diterima. Berdasarkan persamaan diatas diperoleh:

$$
\begin{gathered}
f=\frac{s_{1}^{2}}{s_{2}^{2}} \\
f=\frac{1253,336}{1176,9152} \\
f=1,06 \\
\mathrm{f} \alpha\left(\mathrm{n}_{1}-1, \mathrm{n}_{2}-1\right)=\mathrm{f}_{0,05}(20,20)=2,00
\end{gathered}
$$

Keterangan : $\mathrm{f} \alpha$ (eksperimen $\mathrm{n}_{1^{-}}, \mathrm{n}_{2^{-}} 1$ (20-1) dan control $\mathrm{n}_{2-1}(20-1)$ maka $\mathrm{f}_{0,05}(19,18)=2,92$ dilihat dari tabel nilai kritis distribusi f.
Berdasarkan harga $\mathrm{f}_{\text {hitung }}=1,06$ dan $\mathrm{f}_{\text {tabel }}$ $=2,85$ maka $\mathrm{f}_{\text {hitung }} \leq \mathrm{f}_{\text {tabel. }}$ Maka $\mathrm{H}_{\mathrm{o}}$ diterima, jadi dapat disimpulkan bahwa varians-varians kedua kelas adalah homogen.

\section{Uji Normalitas eksperimen}

Uji normalitas diperlukan untuk mengetahui apakah data dari masing-masing kelas dalam penelitian ini terdistribusi normal atau tidak. Berdasarkan hasil perhitungan kelas eksprerimen diperoleh $\bar{x}_{1}=76,3$ dan $S_{1}=35,40$ kemudian perlu ditentukan batas-batas kelas interval untuk menguji normalitas kelas eksperimen.

Berdasarkan taraf distribusi dapat dilihat bahwa banyak kelas adalah $=6$ sehingga $\mathrm{dk}=6$ $3=3$ dan peluang $1-\frac{1}{2} \alpha$ dengan $\alpha=0,05$ maka diperoleh

$$
\mathrm{x}^{2} 0,975(3)=9,35 \text { Sedangkan } \mathrm{x}^{2} \text { hitung }=-5,064
$$

Oleh karena itu $\mathrm{x}^{2}$ hitung $<\mathrm{x}^{2}$ tabel maka $\mathrm{H}_{\mathrm{o}}$ diterima dan dapat disimpulkan bahwa data dari siswa kelompok ekprimen mengikuti distribusi normal.

\section{Uji Normalitas kontrol}

Uji normalitas diperlukan untuk mengetahui apakah data dari masing-masing kelas dalam penelitian ini berdistribusi normal atau tidak. Berdasarkan hasil perhitungan kelas kontrol diperoleh $\bar{x}_{2}=57,6$ dan $S_{2}=34,30$ kemudian perlu ditentukan batas-batas kelas interval untuk menguji normalitas kelas kontrol. 
Taraf distribusi dapat dilihat bahwa banyak kelas adalah $=6$ sehingga $\mathrm{dk}=\mathrm{k}-3=(6-3)$ dan peluang $1-\frac{1}{2} \alpha$ dengan $\alpha=0,05$ maka diperoleh $\mathrm{x}^{2}{ }_{0,975(3)}=9.35$. Sedangkan $\mathrm{x}^{2}$ hitung $=-21,6239$ Oleh karena itu $\mathrm{x}^{2}$ hitung $<\mathrm{x}^{2}$ tabel maka $\mathrm{H}_{\mathrm{o}}$ diterima dan dapat disimpulkan bahwa data dari siswa kelompok kontrol mengikuti distribusi normal.

\section{Tinjauan Terhadap Hipotesis}

Tinjauan terhadap hipotesis bertujuan untuk mengetahui apakah hipotesis yang dirumuskan dapat diterima atau ditolak. Dari perhitungan sebelumya diperoleh nilai rata-rata kelas eksperimen $\bar{x}_{1}=76,3$ dan $\mathrm{s}_{1}^{2}=1253,336$ dan nilai rata-rata untuk kelas kontrol $\bar{x}^{2}=57,6$ dan $\mathrm{s}_{2}^{2}=$ maka: 1176,9152 .

$$
S^{2}=\frac{\left(n_{1}-1\right) S_{1}^{2}+\left(n_{2}-1\right) S_{2}^{2}}{n_{1}+n_{2}-2}
$$

$$
\begin{aligned}
& s^{2} \\
& =\frac{(20-1) 1253,336+(19-1) 1176,9152}{20+19-2} \\
& s^{2} \\
& s^{2}=\frac{(19) 1253,336+(18) 1176,9152}{37} \\
& s^{2}=\frac{44997,858}{37} \\
& s^{2}=1261,1583 \\
& s=\sqrt{1261,1583} \\
& \mathrm{~s}=35,51
\end{aligned}
$$

Maka T diperoleh:

$$
\begin{aligned}
& t=\frac{\overline{x_{1}}-\overline{x_{2}}}{S \sqrt{\frac{1}{n_{1}}+\frac{1}{n_{2}}}} \\
& t=\frac{76,3-57,6}{35,51 \sqrt{\frac{1}{20}+\frac{1}{19}}} \\
& t=\frac{18,7}{35,51 \sqrt{0,05+0,052}}
\end{aligned}
$$

$$
t=\frac{18,7}{35,51(0,102)}
$$

$$
t=\frac{18,7}{3,62202}
$$$$
t=5,16
$$

Dengan taraf signifikan $\alpha=0,05$ dan derajat kebebasan $\mathrm{dk}=(\mathrm{n}+\mathrm{n}-2)=(20+19-2)=$ 37. Maka dari daftar distribusi t diperoleh $t(0,05)$ $(37)=1,68$. Pengujian hipotesis dilakukan pada taraf signifikan $\alpha=0,05$ dan derajat kebebasan 37.

Rumusan hipotesis dalam penelitian ini adalah sebagai berikut:

$\mathrm{H}_{0}: \mathrm{t}$ hitung $\leq \mathrm{t}$ tabel $=$ Penerapan model pembelajaran Contextual Teaching and Learning (CTL) dapat meningkatkan prestasi belajar siswa di Kelas $\mathrm{X}$ SMA Negeri 1 Peukan Baro.

$\mathrm{H}_{\mathrm{a}}: \mathrm{t}$ hitung $\geq \mathrm{t}$ tabel $=$ Penerapan model pembelajaran Saintifik dapat meningkatkan prestasi belajar siswa di 
Pengaruh Pendekatan Saintifik Dan Pendekatan Contextual Teaching And Learning (CTL) Terhadap Prestasi Belajar Sejarah Siswa Di Sma Negeri 1 Peukan Baro Kabupaten Pidie Heri Fajri, Putri Raisa
Kelas X SMA Negeri 1 Peukan Baro.

Kriteria pengujian hipotesis tersebut adalah : Terima $\mathrm{H}_{0}$, jika $\mathrm{t}_{\text {hitung }} \leq \mathrm{t}$ tabel, terima $\mathrm{H}_{\mathrm{a}}$ jika $t_{\text {hitung }} \geq \mathrm{t}_{\text {tabel. }}$.

Berdasarkan hasil pengolahan data dengan taraf signifikan $\alpha=0,05$ dan derajat kebebasan $=37$ dan daftar distribusi $\mathrm{t}$ diperoleh $=1.68$ sedangkan $\mathrm{t}_{\text {hitung }}=5,16$ ini berarti $\mathrm{t}_{\text {hitung }}$ $\geq \mathrm{t}$ tabel sehingga $\mathrm{H}_{\mathrm{a}}$ ( hipotesis alternatif) dapat diterima yaitu terdapat pengaruh penerapan model pembelajaran Contextual Teaching and Learning (CTL) dapat meningkatkan prestasi belajar siswa di Kelas X SMA Negeri 1 Peukan Baro.

Berdasarkan hasil penelitian yang di lakukan oleh peneliti di SMA Negeri 1 Peukan Baro dengan menerapkan penerapan model pembelajaran Contextual Teaching and Learning (CTL) dapat meningkatkan prestasi belajar siswa memperoleh hasil pengolahan data diperoleh nilai tertinggi siswa kelas Eksperimen sebesar 90 dan nilai terendah sebesar 60. Sedangkan nilai tertinggi kelas kontrol sebesar 80 dan terendah 20. Untuk nilai rata-rata siswa kelas eksperimen 76,3 dan untuk siswa kelas kontrol sebesar 57,6.

Untuk melakukan pengujian dengan menggunakan rumus uji $\mathrm{t}$ terlebih dahulu dilakukan uji homogenitas. Uji homogenitas dilakukan untuk mengetahui sampel penelitian ini berasal dari populasi yang sama, sehingga hasil penelitian dapat berlaku bagi populasi.
Hasil uji homogenitas dalam penelitian ini menunjukkan bahwa $F_{\text {hitung }} \leq F_{\text {tabel }}$ maka hipotesisnya adalah terima $\mathrm{H}_{\mathrm{o}}$, jadi dapat disimpulkan bahwa varian data kedua kelas adalah homogen.

Setelah kedua data dinyatakan homogen selanjutnya data tersebut diuji normalitas, uji normalitas diperlukan untuk mengetahui apakah data dari masing-masing kelas terdistribusi dengan normal atau tidak. Dalam pengujian normalitas menunjukkan bahwa kedua nilai tersebut terdistribusi normal ini terbukti hasil $\mathrm{x}^{2}$ hitung $<\mathrm{x}^{2}$ tabel yaitu $-110,773 \leq 9,35$ untuk kelas eksperimen dan kelas kontrol adalah -95,3104 < 9,35 .

Apabila data sudah dinyatakan homogen dan terdistribusi normal barulah uji $t$ dapat dilakukan. Berdasarkan hasil pengolahan data dengan taraf signifikan $\alpha=0,05$ dan derajat kebebasan $=37$ maka diperoleh $\mathrm{t}_{\text {tabel }}=1,68$. Sedangkan $t_{\text {hitung }}=5,16$ ini berarti $t_{\text {hitung }} \geq$ tabel. Maka hipotesisnya adalah terima $\mathrm{H}_{\mathrm{a}}$ dan tolak $\mathrm{H}_{\mathrm{o}}$. Yaitu terdapat perbedaan hasil belajar siswa kelas eksperimen dengan siswa kelas kontrol. Jadi dalam penelitian ini diterima kebenarannya karena sesuai dengan penguji hipotesis dimana hipotesisnya beranggapan bahwa terdapat perbedaan nilai prestasi belajar siswa antara kelas ekperimen dengan menggunakan model pembelajaran Contextual Teaching and Learning (CTL) dengan siswa kelas kontrol dengan menggunakan model 
pembelajaran saintifik di SMA Negeri 1 Peukan Baro Kabupaten Pidie.

\section{SIMPULAN}

Pengaruh pendekatan saintifik dan pendekatan

Contextual Teaching and Learning (CTL) terhadap prestasi siswa di SMA Negeri 1 Peukan Baro Kabupaten Pidie dengan nilai rata-rata untuk siswa kelas ekperimen $=76,3$ dan untuk siswa kelas kontrol di peroleh sebesar $=57,6$. Simpangan baku untuk kelas eksperimen= 32,797 dan kelas kontrol= 23,63 untuk hasil uji homogenitas $F_{\text {hitung }}=1,06$ dan $F_{\text {tabel }}=2,92$ maka
$F_{\text {hitung }} \leq \mathrm{F}_{\text {tabel }}$ sehingga dapat disimpulkan bahwa kedua kelas homongen. Untuk uji normalitas kelas ekperimen diperoleh hasil $\mathrm{X}^{2}$ hitung $=-5,064$ dan $X_{\text {tabel }}^{2}=9,35$. Untuk uji normalitas kelas kontrol diperoleh hasil $X^{2}{ }_{\text {hitung }}=-21,6239$ dan $X_{\text {tabel }}^{2}=9,35$. Oleh karena $X^{2}{ }_{\text {hitung }} \leq X_{\text {tabel }}^{2}$ maka $\mathrm{H}_{\mathrm{o}}$ diterima dan dapat disimpulkan bahwa data dari kedua kelas mengikuti distribusi normal. Berdasarkan pengujian hipotesis dengan menggunakan uji $\mathrm{t}$ diperoleh nilai $\mathrm{t}_{\text {hitung }}=5,16$ dengan signifikan $t_{\text {tabel }}=1,68$ maka hipotesisnya adalah terima $\mathrm{H}_{\mathrm{a}}$ dan tolak $\mathrm{H}_{\mathrm{o}}$.

\section{DAFTAR PUSTAKA}

Alwasilah, 2008. Pokoknya Kualitatif: Dasar-dasar Merancang dan. Melakukan Penelitian Kualitatif. Jakarta: Pustaka Jaya.

Daryanto, 2014. Pembelajran Tematik, Terpadu, Terintegrasi. Yogjakarta: Gava Media

Hatabarat, 2005. Prestasi Belajar Siswa. Jakarta : Erlangga

Kasasih, 2000. Pendekatan Saintifik dan Kontekstual. Jakarta : Aksara

M. Hosnan, 2014. Pendekatan Saintifik dan Kontekstual Dalam Pembelajaran. Bandung: PT Remaja Rosdakarya

Muhibbin Syah. 2011. Psikologi Belajar. Jakarta : Raja Grafindo Persada.

Nana Syaodih, 2007. Perencanaan Pengajaran. Jakarta: Rineka Cipta.

Reynolds, 2010. Metodelogi Penelitian. Jakarta : Erlangga

Sardiman, 2011. Interaksi dan Motivasi Belajar Mengajar. Jakarta: Rajawali Press.

Setiawan, 2007. Model Pembelajaran Cooperatif dan Inovatif. Jakarta : Aksara

Sulaiman, 2004. Prinsip-prinsip Pembelajaran. Bandung: PT Remaja Rosdakarya

Sumadi Suryabrata, 2006. Psikologi Pendidikan. Jakarta: PT Raja Grafindo 
Jurnal Geuthèë: Penelitian Multidisiplin

Vol. 03, No. 01, (Maret, 2020), pp. 400-416.
Pengaruh Pendekatan Saintifik Dan Pendekatan Contextual Teaching And Learning (CTL) Terhadap Prestasi Belajar Sejarah Siswa Di Sma Negeri 1 Peukan Baro Kabupaten Pidie Heri Fajri, Putri Raisa

Sudjana, 2005. Metode Statistika Edisi ke-6. Bandung : Tarsito.

Syaiful Bahri Djamarah, 2006. Strategi Belajar Mengajar. Jakarta : PT Rineka. Cipta.

Suryabrata, 2013. Psikologi Pendidikan. Jakarta: PT. Raja. Grafindo

Trianto, 2009. Melaksanakan Penelitian Tindakan Kelas Itu Mudah, Jakarta : Bumi Aksara 